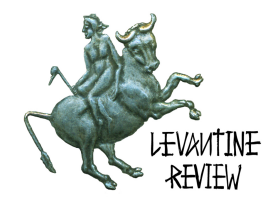

\title{
COLLECTIVE MEMORY AND THE ALHAMBRA: TWO DIFFERING PERSPECTIVES
}

\author{
April Najjaj*
}

In October 2001, only a few weeks after 9/11, Osama bin Laden and his deputy, Ayman alZawahiri, gave internationally televised speeches which made reference to the history of Islam, of the struggle they perceived between Islam and Christianity, and of the modernday expressions of that supposed conflict. In his own speech that day, al-Zawahiri insisted that "'the tragedy of al Andalus" would not be repeated.' ${ }^{1}$ He offered no explanation for this historical reference, for he assumed that his intended audience would know and understand that he was referring to a historical event that had occurred over five hundred years ago-in 1492, to be precise. In that year, the last kingdom of Islamic Iberia, the Nasrids of Granada, surrendered to Ferdinand and Isabella. At the time of the capitulation, the Catholic kings had assured the Muslim population of Granada that they would be free to continue their own religious and cultural traditions; nevertheless, within ten years of the conquest, those assurances were forgotten, and the remaining Muslim population was first forcibly converted to Christianity, relocated to other areas of the country, and ultimately expelled from Spain by the early 1600s, ironically long after Islam had ceased to be a significant religious tradition in the peninsula.

The physical space where the drama of this surrender played out is still standing todayreferred to as the Alhambra in Spanish and al-Qasr al-Hamra' in Arabic, meaning the 'red fortress' because of the red clay used in the construction of its buildings and walls. This palace-city had been the royal residence and seat of government for the Nasrid kingdom of Granada from the beginnings of the dynasty in 1238 until its final defeat some 250 years later. The foundations of the Alhambra date back several centuries earlier in the history of al-Andalus, but the site reached its greatest expression, both architecturally and historically, during the fourteenth century when it served as both a royal residence and a seat of government for the Nasrid sultans. After the Christian conquest, the site became a favorite occasional residence for Spanish royalty for the next 150 years, until the state of disrepair and the parceling out of sections as rewards for military service ended any permanent habitation at the site. It was occupied by French troops in the early 1800s, with the medina area suffering heavy damage upon the French withdrawal near the end of the Napoleonic wars. After that, occasional visitors came and went until restoration and

1 Susan Sachs, “Bin Laden Images Mesmerize Muslims," New York Times (October 9, 2001), 6. 


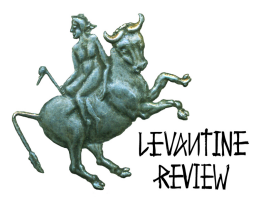

conservation of the site began in earnest by the 1930s, and it was named a UNESCO World Heritage Site in 1984. Archeological work there is ongoing, and the many tour buses that pull up during the summer months have made the site the number one tourist attraction in Spain today.

Historical locations and the events that took place there are continually filtered through the lens of the modern world, and events and places from the distant past go through this filtering process with every new generation, creating a collective memory built up over time where the public knowledge of the event is most often not the same thing as the historical facts. In addition, the collective memory of a monument can be referred to by Pierre Nora's term as a lieu de mémoire, a memory site, and comes to symbolize some aspect of a monument's past that gives meaning to a modern-day audience. ${ }^{2}$ With a monument like the Alhambra, the lens through which the memory site passes changes considerably depending upon the historical context and perspective of the audience.

Since its inception in historical scholarship through the work of Maurice Halbwachs and others, collective memory has become a very broad term to encompass a variety of different approaches to historical and sociological studies. In this study, I use the term 'collective memory' in the sense of 'public memory', referring to the ideas and representations of history usually proposed and promoted over time by those in power with the resources to create or project those images. It is a memory that serves selected interests or political or ideological positions and then absorbs and perpetuates those images to the target society as a whole. It is about a popular history, or even a 'symbolically reconstructed past,' as George Mead referred to it, that attempts to explain and make sense of the past according to the context of today. ${ }^{3}$ Such remembrances can be found expressed in intentional public remembrances of historical events, from the names of businesses and re-creations of architectural styles and artistic tributes to annual holidays and commemorations. Celebrations and repetitions of this kind are what help to give a people a social identity and a historical consciousness, a sense of belonging to a particular group that finds reinforcement in that identity through remembrance of a shared history. Especially for historical events beyond living memory, individuals are told or taught their history, and that is where the selection and interpretation process begins. Such public commemorations are necessary and important in order to maintain the ties with the past that give a people their foundation, their sense of belonging and identity, and a way of reconstructing or re-organizing an historical discourse to fit a particular perspective or agenda.

2 Pierre Nora, "Between Memory and History: Les Lieux de Mémoire," Representations (26) Spring 1989, 7-25.

3 See George H. Mead, "The Nature of the Past," in Essays in Honor of John Dewey ed. John Coss (New York: Henry Holt \& Co., 1929), 235-42. 


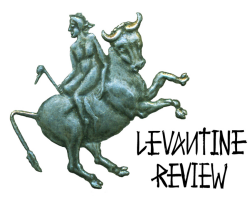

In an article entitled, "Al-Andalus: Between Myth and History," María Jesús Rubiera Mata and Mikel de Epalza have written that the ideas of cultural splendor and of a paradise lost with Al-Andalus are images that have endured in the Islamic world since the sixteenth century, specifically referencing the writings of al-Maqqari. ${ }^{4}$ I would suggest, however, that the Christian world has also employed historical references to the region to serve their own purposes that often do not encourage an emphasis on the "common past that both [Spaniards and Arabs] can appreciate," as the authors of this article suggest. ${ }^{5}$ Because the Alhambra specifically, and the lands of Al-Andalus in general, passed into the hands of the Spanish Christians and became incorporated into the country recognized as Spain today, the Spanish themselves control the dominant discourse on how the building is represented and preserved, and thus they choose what aspects of its history to emphasize, downplay, or ignore in the public sphere in order to present the image of the site they wish their audience to remember.

Considering another monument of Islamic Spain, the Grand Mosque in Córdoba, can give a window into what to expect when it comes to the modern-day Spanish collective memory of their Islamic heritage, for the brochure given out to tourists at the mosque in Córdoba continually refers to the building as a cathedral and describes the almost eight hundred years of Islamic rule in Spain as an "interruption" or an "occupation" in an otherwise continuous Christian domination of the peninsula dating back to the time of the Romans. Archeologists at the site have dug beneath the floors of the building to find the early medieval foundations of the Christian church that had stood there before the Muslim conquest, and the tour guide is sure to point this out to visitors; however, the guides neglect to mention that the space was shared by both Christian and Muslim populations after the conquest and that as the Muslim population of Córdoba grew, the Umayyad emir bought the building from the Christians. The site would then be expanded over the next two hundred years into what becomes the Grand Mosque, while the Christians had by then built a new church. The site would revert back to a church after the Christian conquest of the city in 1236; it is considered and is marketed as a cathedral today, and tourists cannot enter the building on Sunday mornings because services are still held there.

Nevertheless, an Egyptian journalist named Muhammed Farid, who visited Córdoba at the beginning of the twentieth century, wrote that despite the bells now housed in the minaret

\footnotetext{
${ }^{4}$ See al-Maqqari, Ahmad ibn Muhammad, The History of the Mohammedan Dynasties in Spain; extracted from the Nafhu-t-tíb min ghosni-l-Andalusi-r-rattíb wa tárikh Lisánu-d-Dín Ibni-l-Khattíb, (London: Oriental Translation Fund of Great Britain and Ireland, 1840-43; reprint, New York: Johnson Reprint Corp., 1964).

${ }^{5}$ María Jesús Rubiera Mata and Mikel de Epalza, "Al-Andalus: Between Myth and History," History and Anthropology 18:3 (September 2007), 272.
} 


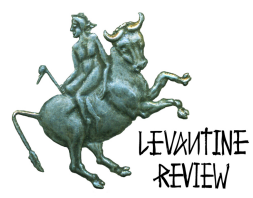

and the statues and crosses at the entrances, these modern additions do not change the Islamic character of the building, which still continues to recite the call to prayer and the shahadat-la illaha illa Allah wa Muhammadan rasul Allah ("There is no god but Allah, and Muhammad is his Prophet.") ${ }^{6}$

Farther south with the Alhambra and the city of Granada, this emphasis on the Christian and Western-oriented history of Spain can be seen in the annual commemoration of El Día de la Toma (literally, the 'Day of the Taking'), referring to the day when the last sultan of the Nasrids, Muhammad XII, or Boabdil as he was known to the Christians, surrendered to Ferdinand and Isabella within the walls of the Alhambra - on January 2, 1492-signifying not only the end of the Nasrid kingdom but also that of al-Andalus. Rituals are commonly used to communicate a form of authority and reflect the dominant discourse of an event or idea played out in the public sphere, and in this instance, that authority is communicated in several ways. Only on this day of the year, the bell is rung in the tower of the Alhambra that faces the city of Granada. In addition, downhill in the city itself, there is a military parade with men in more or less period costumes, marching bands, the waving of various Spanish flags, speeches by local dignitaries, with crowds of spectators lining the streets to the cathedral of Granada, which is the burial place of Ferdinand and Isabella, where a church service is then held.

Based on Youtube footage of the annual parades, not everyone in Granada is pleased with this officially-sanctioned collective memory, as protestors can be seen carrying signs calling the festival racist and fascist, but the police quickly suppressed the noisiest of them and the parade continues on. Eviatar Zerubavel wrote that commemorations are "highly formulaic plot structures we often use for narrating the past" that emphasize whatever aspect of the history is considered to be the most important by whoever is doing the remembering. ${ }^{7}$ Because the Spanish now control the territory as well as the material remains, the lieux de mémoire of the former al-Andalus, they also control the official expressions of the history of the region and the uses of those locations and choose the aspects of the history to emphasize and the other aspects requiring a collective or selective amnesia to ignore and forget.

In addition, in considering a broader context, the annual January 2 commemoration is not only a celebration of the end of al-Andalus but also of the triumph of Christianity over Islam and the end of the Reconquista, or Reconquest, a historical theory created by Spanish

6 Víctor Morales Lezcano, "La percepción de al-Andalus en libros de viajes de autores árabes," in J.A. González Alcantud and A. Malpica Cuello, eds., Pensar La Alhambra, Granada: Diputación Provincial de Granada, 2002, 256.

${ }^{7}$ Eviator Zerubavel, Time Maps, Collective Memory and the Social Shape of the Past," Chicago: University of Chicago Press, 2003, 4. 


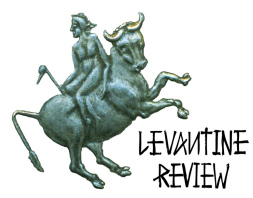

historians in the earlier twentieth century to try to create order and a sense of progression to an otherwise turbulent and contradictory time in the history of medieval Spain, creating what Nora refers to as a "cult of continuity" that helps a people to establish their origins and to assign importance or a sense of the sacred to those origins. ${ }^{8}$ In addition, use of the popular images created by nineteenth century Orientalism, including authors such as Washington Irving and painters like Gabriel Raya Morcillo, allow for the attraction of the exotic to bring in tourists but also allow Spaniards themselves to see those traditions as foreign caricatures far removed from the modern-day and not really a part of the heritage of European emphasis that the country presently chooses to follow.

Peter Burke has written that, "It is often said that history is written by the victors. It might also be said that history is forgotten by the victors. They can afford to forget, while the losers are unable to accept what happened and are condemned to brood over it, relive it, and reflect how different it might have been."9 In the case of al-Andalus, the Arab and Islamic world has been brooding over a loss that happened five hundred years ago; the loss has not been forgotten, as the memory of al-Andalus is continually repeated and referenced in the Islamic world of today.

From that Islamic perspective, the Alhambra and al-Andalus are filtered through a very different lens of collective memory, most often the one referenced earlier by Rubiera Mata and Epalza - one of nostalgia and of regret for a paradise, a culture, and a people that have been lost to the dar al-Islam forever. This was clearly the reference Ayman al-Zawahiri was relying upon in his speech in 2001, and just as in the Christian Spanish sense, the Arab and Islamic attitudes regarding their history are bound up with events since 1492, especially considering the legacies of European colonialism and of Arab nationalism. Throughout Arab and Islamic history, nostalgia and loss for cities of the past is a recurring theme-not surprising for a civilization where the power and authority of a new dynasty had often been reflected in the founding of a new capital city. ${ }^{10}$ Such laments for the loss of cities (or even campsites) have been reflected in poetry dating back to the pre-Islamic period, as well as later with the destruction of Andalusi Umayyad Córdoba in the eleventh century or of Abbasid Baghdad after the Mongol invasion in the thirteenth century. ${ }^{11}$ Even in modernday popular culture, references to al-Andalus can be found throughout the Islamic worldfrom literature, poetry, and art to the names of buildings, cinemas, and restaurants, helping

\footnotetext{
8 Nora, "Between Memory and History," 16.

${ }^{9}$ Peter Burke, "History as Social Memory," in Thomas Butler, Memory, History, Culture and the Mind, Oxford: Basil Blackwell, Ltd., 1989, 106.

10 See Paul Wheatley, The Places Where Men Pray Together, Cities in Islamic Lands Seventh

Through the Tenth Centuries," Chicago: University of Chicago Press, 2001.

11 Víctor Morales Lezcano, "La percepción de Al-Andalus en libros de viajes de autores árabes," 251.
} 


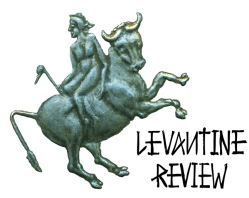

to create a historical anchor that is now often used as a form of remembrance and, at times, a mark of splendor and luxury, even if the items described by those terms often bring to mind little or nothing of the Alhambra or of al-Andalus.

To wit, I bought a set of traditional tea cups in a kind of hardware store near my apartment in Kuwait; the box proudly proclaimed "El Andalos," but when I eagerly opened the box and looked, it was a set of clear glass tea cups for everyday use that were rather plain and certainly functional, but brought to my mind absolutely nothing of Al-Andalus. The same is true of the "Al-Andalus" appliance store near the Al-Mubarakiyya souk or the "Al-Andalus" electrical store in the Hawally region of Kuwait City, or the many restaurants named "The Alhambra," such as the one in the Avenues Mall-it's an interesting restaurant with a rather pricey buffet more Indian in inspiration than Middle Eastern or North African; the mosaic on the back wall depicting the Hall of the Ambassadors and the moderately successful copying of the plaster decorative columns that attempt to recreate the style at the Alhambra are the only aspects that bring to mind its namesake in southern Spain.

The terms 'Alhambra' and 'al-Andalus' have simply become names used to commemorate a particular cultural identity but also to convey a sense of luxury, splendor, and expensive tastes even though what is being described with these adjectives may have little or nothing to do with the original meanings of the words. It's a reference to a cultural heritage that has become part of the collective memory of a land and a culture that was lost centuries ago. One exception I found, however, can be seen in the Emir's reception room to the side of the main prayer hall in the Grand Mosque of Kuwait. Although at times the color scheme is more muted, the decorative theme chosen for the room literally transports the viewer five thousand miles away to the halls of the Alhambra, including the patterns of the tile work covering the walls and the muqarnas, the stalactite-style ornamentation where wall and ceiling come together; a hallmark of Andalusian decorative style.

The modern-day effort to remember the glory days of al-Andalus, real or imagined, can also be seen as a reaction against the forces of European colonialism in the nineteenth and twentieth centuries and serves as a collective memory to the bruised and battered ego of the Arab world where, at least in the medieval period, the Arabs and Muslims had an outpost of Islamic culture in what eventually becomes a Western Christian land. The Arab nationalist poet Nizar Qabbani served as the Syrian ambassador to Spain from 1962-1966 and visited the south of Spain a number of times. Much of his poetry is written in a populist style accessible to a wide Arabic-speaking audience where he encouraged the rejection of political instability, social conservatism, and outdated traditions that he believed would continue to leave the Arab world unable to fend off or compete with the West. However, he also continued a long-standing tradition of rithā al-mudun ("city elegies") where poems are written in praise of cities or palaces. In this context, he wrote numerous pieces addressed to Damascus and Beirut and Jerusalem. During his time in Spain, Qabbani also wrote 


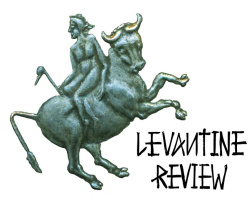

several poems addressed to Granada where, despite the nationalism and lack of sentimentality often found in his other works, he relies on a sense of nostalgia, of romanticism, and of loss typical throughout the Arab and Islamic world in regards to the lands of the former al-Andalus. In his poem, "Andalusian Pearls," he writes:

Only from Granada and the Banu-l-Ahmar what the stories tell that "Only God Prevails" [motto of Nasrid dynasty and found in inscriptions at the Alhambra] in every nook and cranny. All that's left is its fortress like a naked Venus still living a love story ended. Five centuries gone by since the "Little King" [BoabdilMuhammad XII] left Spain. But still our little hatreds continue. And that tribe mentality is still in our blood as before. We speak everyday with scimitars. We think with our fingernails.

Later in this same poem, he continues:

They all passed through five centuries, and the term Arabism, still is a sad flower in a pitcher, a hungry and naked child that we stick against the wall of hatred and rancor. Five centuries passed-ay, my love!-and it is as if we were only now leaving Spain. ${ }^{12}$

At the time that Qabbani resided in Spain in the 1960s, pan-Arabism was a popular idea. Gamal Abdul Nasser was ruling in Egypt, and the Arab-Israeli conflict was well underway. On the one hand, the 1960s was a period of pride for efforts to stand up against Western involvement in the post-colonial Middle East but also one of continuing struggles with political instability and dictatorship. Qabbani's work is a reflection of a militant nationalism in the face of Arab political weakness and division and continued Western encroachment, but at the same time is a voice and a mentality that cannot quite shake off the old models of nostalgia and feelings of loss where the "little hatreds continue" and the "tribe mentality is still in our blood as before."13

Pierre Nora also writes that "for there to be a sense of the past there had to be a 'before' and an 'after,' a chasm had to intervene between the present and the past." 14 For the history of al-Andalus and the modern-day interpreters of its history, that chasm is 1492, creating a profound and fundamental break from the political, religious, and cultural context of its Islamic founders to a distinct Christian context afterwards. Together with a focus in time, a focus in place is also necessary for collective memories, creating a spatial

12 Morales Lezcano, "La percepción de Al-Andalus en libros de viajes de autores árabes," 258. See also www.poemhunter.com/NizarQabbani. Trans. Ruy Burgos-Lovèce and April Najjaj.

13 Ibid.

14 Nora, “Between Memory and History," 16.

ISSN: $2164-6678$ 


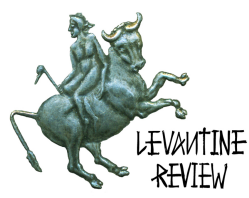

dimension that gives definition and physical legitimacy to the events being remembered.15 For the Spanish and Christian side, that focus on the Alhambra in 1492 signifies the final defeat of al-Andalus, the end of the Reconquest, and the territorial and religious unification of Spain. These collective memories have since given direction to the country and, at the risk of over-generalization, have been so taken to heart in Spain that many people in the country deny that the eight hundred years of Muslim rule had any lasting effects on what becomes Spanish culture; part of the intention of the concept of 'reconquista' was to create a legitimacy for the country, a foundational myth for the creation of the modern state that would ennoble the struggles of the peninsula with a link back to the eighth century and give a sense of determinism and inevitability that did not exist historically speaking, but that has become part of the collective memory of the country. ${ }^{16}$ In the process, the Islamic influences that continued in the culture after 1492 - in the art and architecture, food, and language, for example-have become so internalized into the Spanish national consciousness so as to be no longer recognized anymore as part of an Islamic heritage. Together with a general hostility in the West towards the world of Islam in the modernday, Spain has largely rejected its Islamic heritage and encouraged the suppression and manipulation of its collective memory in favor of downplaying the role of Islam and instead emphasizing its Roman, Germanic and Christian heritage.

For the Arab and Islamic side, the surrender of the Alhambra in 1492, as well as the last remnants of al-Andalus, signifies the final loss of a territory and a people that represented the farthest western extent of the Muslim world and the end of the splendor in art and architecture that is still represented in the physical remnants that are still extant, as well as the many imitations of Andalusian architectural and artistic styles that exist throughout the Middle East. While these interpretations constructed from both sides of the debate are overly simplified and historically inaccurate, the collective memories of peoples from both perspectives will continue to pick and choose what aspects of the historical record they want to remember and which ones they find more convenient and comforting to ignore or forget.

From both perspectives, a continuity of collective memory of al-Andalus can be seen as a search for the roots of their respective cultures. In the case of the Spanish and Christian perspective, the victory over al-Andalus has been used as the catalyst for the reclaiming of the Roman and Christian heritage that they assert was always prevalent in the peninsula, even when "interrupted" by Islamic rule for eight hundred years. For the Arab and Islamic side, al-Andalus is often referenced as the glory days of the Islamic world, such as in the

15 See Nathan Wachtel, "Memory and History," trans. Sharon Romeo. History and Anthropology 2 (1986), 207-224.

16 See Bernard Lewis, History-Remembered, Recovered, Invented, Princeton: Princeton University Press, 1975, 62. 


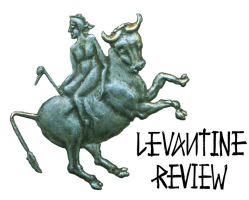

commencement address at the university where I work in Kuwait where the speaker referred to the glory days of scientific studies in al-Andalus during the Islamic Middle Ages and that the Islamic world should strive to achieve that leadership again. In addition, the loss of al-Andalus and the subsequent expansion and domination of the Islamic world by the West, has led to other feelings of nostalgia and regret reflected in the literature, art, and material cultures of the modern-day Middle East. From a modern-day perspective, Muslims can identify with the people of the past in al-Andalus because both were peoples whose religion and culture were and are still considered to be under attack by Western powers, albeit many centuries apart.

The memory site of the Alhambra is a mirror into the world that created it, and even though the monument itself has survived, the world that created it ended long ago. ${ }^{17}$ However, memories of that world can still be seen in the decorative program of the site, serving as a visual reminder of who built it and what it has been designed to represent. The Quranic references and panegyric poetry on the walls are reminders of the original history of the building, reminding Muslims of the past when the region was part of the Muslim world. For the Christians, however, such reminders serve as a memory rejection or reinterpretation to signify what they prefer to see-a site today in the hands of the Christians. The interpretations of that world from both perspectives are recreated and restructured with every succeeding generation, neither of which bother much with historical accuracy.

It is interesting to note that the Alhambra has come to be a significant space in the modernday interpretations of two distinct historical traditions, but in its own day, the palace-city was a small residence of a minor and impoverished kingdom on the outer edge of the Islamic world. Ibn Battuta and Ibn Khaldun, both famous fourteenth century North African travelers, came to Granada and stayed at the Alhambra in the 1350s and early 1360s, and neither of them even commented on the place; it was an unremarkable location lost in the shuffle between the expansion of the Ottomans in the East and the consolidation of Christian Spain to the West. However, in the modern day, the mythic qualities and romantic notions of the Alhambra are used to further ideas and assumptions on both sides of the story about their own respective cultures and histories and to continue to choose an interpretation of events that furthers a particular narrative of each side that may or may not have much to do with historical realities. The palace-city of the Alhambra is a public space with a plurality of pasts, "forever open to the full range of its possible significations," which evolve over time considering the audience. ${ }^{18}$

17 Nora, "Between History and Memory," 22.

18 Ibid, 24. 


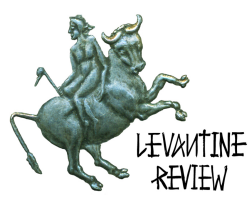

The idea of the Alhambra and of al-Andalus becomes open to varying interpretations of collective memory that further the needs and desires of both sides to create an identity and a consciousness based upon the past-whichever version of the past is chosen to remember-because the history is found somewhere in-between.

* April L. Najjaj holds B.A. and M.A. degrees in History from the University of ArkansasFayetteville and a Ph.D. in History from Boston University. She is currently an Assistant Professor of History at the Gulf University for Science and Technology in Kuwait. 


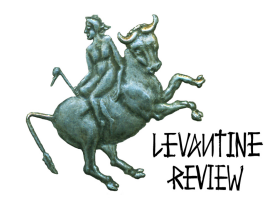

\section{Bibliography}

Alcantud González, J.A., and A. Malpica Cuello, eds. Pensar La Alhambra. Granada, Spain: Diputación Provincial de Granada, 2001.

Anderson, Glaire, and Mariam Rosser-Owen, eds. Revisiting Al-Andalus, Perspectives on the Material Culture of Islamic Iberia and Beyond. Leiden: Brill Publishers, 2007.

Beckwith, Stacy N., ed. Charting Memory: Recalling Medieval Spain. New York: Garland Publishing Group, Inc., 2000.

Butler, Thomas, ed. Memory, History, Culture and the Mind. Oxford: Basil Blackwell Ltd., 1989.

Ciappelli, Giovanni, and Patricia Lee Rubin, eds. Art, Memory, and Family in Renaissance Florence. Cambridge: Cambridge University Press, 2000.

Elinson, Alexander E. Looking Back at Al-Andalus, The Poetics of Loss and Nostalgia in Medieval Arabic and Hebrew Literature. Leiden: Brill Publishers, 2009.

Forster, Kurt. "Aby Warburg's History of Art: Collective Memory and the Social Mediation of Images." Daedalus 105:1 (Winter 1976): 169-176.

Geary, Patrick J. Phantoms of Remembrance, Memory and Oblivion at the End of the First Millenium. Princeton, NJ: Princeton University Press, 1994.

Gilles, John R., ed. Commemorations, The Politics of National Identity. Princeton, NJ: Princeton University Press, 1994.

Halbwachs, Maurice. On Collective Memory. Ed., trans., Lewis A. Coser. Chicago: University of Chicago Press, 1992.

Heidenreich, Luise. Collective Memory, Identity and Place Making in Reunified Berlin. Essay. www.irmgard-coninx-stiflung.de; Internet; accessed July 24, 2013.

Hutton, Patrick H. History as an Art of Memory. Hanover, VT: University of Vermont Press, 1993. 


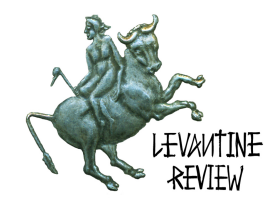

Irving, Washington. Tales of the Alhambra. Granada, Spain: Ediciones Miguel Sánchez, 1993.

Kansteiner, Wulf. "Finding Meaning in Memory: A Methodological Critique of Collective Memory Studies." History and Theory 41 (May 2002): 179-197.

Klein, Kerwin Lee. “On the Emergence of Memory in Historical Discourse.” Representations 69 (Winter 2000): 127-151.

Kulišić, Marija, and Miroslav Tudman. "Monument as a Form of Collective Memory and Public Knowledge." Paper presented at $2^{\text {nd }}$ International Conference on the Future of Information Sciences, Zagreb, Croatia, 2009. http://info.ffzg.hr.

Le Goff, Jacques. History and Memory. New York: Columbia University Press, 1992.

Lewis, Bernard. History-Remembered, Recovered, Invented. Princeton, NJ: Princeton University Press, 1975.

al-Maqqari, Ahmad ibn Muhammad. The History of the Mohammedan Dynasties in Spain; extracted from the Nafhu-t-tíb min ghosni-l-Andalusi-r-rattíb wa táríkh Lisánu-d-Dín Ibni-l-Khattíb. (London: Oriental Translation Fund of Great Britain and Ireland, 1840-43; reprint, New York: Johnson Reprint Corp., 1964).

Mead, George H. "The Nature of the Past," in Essays in Honor of John Dewey, ed. John Coss. (New York: Henry Holt \& Co., 1929).

Monroe, James T. Islam and the Arabs in Spanish Scholarship (Sixteenth Century to the Present). Leiden: E.J. Brill, 1970.

Najjaj, April L. "The Alhambra in Comparative Perspective: Towards a Definition of PalaceCities." (Ph.D. diss., Boston University, 2005).

Nora, Pierre. "Between Memory and History: Les Lieux de Mémoire." Representations 26 (Spring 1989): 7-24.

Qabbani, Nizar. Arabian Love Poems. Ed. and trans. Bassam K. Frangieh and Clementina R. Brown. Colorado Springs, CO: Three Continents Press, 1993.

. On Entering the Sea, The Erotic and Other Poetry of Nizar Qabbani. Trans. Lena Jayyusi and Sharif Elmusa. New York: Interlink Books, 1996. 


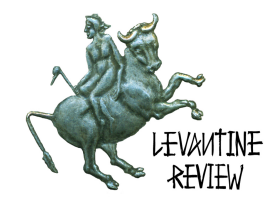

Redstone, Susannah, and Bill Schwarz, eds. Memory, Histories, Theories, Debates. New York: Fordham University Press, 2010.

Roberts, Rachel M. "Salamanca, Spain: Collective Memory in the Urban Space-Time Continuum." Lambda Alpha Journal 36 (2006): 85-95.

Rubiera Mata, Maria Jesús, and Mikel de Epalza. "Al-Andalus: Between Myth and History." History and Anthropology 18:3 (September 2007): 269-273.

Sachs, Susan. “Bin Laden Images Mesmerize Muslims.” New York Times (October 9, 2001): 6.

Schwartz, Barry, Yael Zerubavel, and Bernice M. Barnett. "The Recovery of Masada: A Study in Collective Memory." The Sociological Quarterly 27:2 (1986): 147-164.

Said, Edward. Culture and Imperialism. New York: Vintage Books, 1993.

Starn, Randolph, and Natalie Zemon Davis. "Introduction.” Representations 26 (Spring 1989): 1-6.

Vines Millet, Cristina. "Sobre la vida interna de la Alhambra entre los siglos XVIII y XIX," Cuadernos de la Alhambra 13 (1977): 33-60.

Wachtel, Nathan. "Memory and History." Trans. Sharon Romeo. History and Anthropology 2 (1986): 207-224.

Wheatley, Paul. The Places Where Men Pray Together, Cities in Islamic Lands Seventh Through the Tenth Centuries. Chicago: University of Chicago Press, 2001.

Word, Nancy. Vectors of Memory, Legacies of Trauma in Postwar Europe. Oxford: Berg Publishers, 1999.

Zerubavel, Eviatar. Time Maps, Collective Memory and the Social Shape of the Past. Chicago: University of Chicago Press, 2003. 